\title{
Prevention of Postasphyxial Increase in Lipid Peroxides and Retinal Function Deterioration in the Newborn Pig by Inhibition of Cyclooxygenase Activity and Free Radical Generation
}

\author{
SYLVAIN CHEMTOB, MARIE-SYLVIE ROY, DANIEL ABRAN, HENDRIKA FERNANDEZ, AND \\ DAYA R. VARMA
}

Departments of Pediatrics, Pharmacology and Ophthalmology, Research Center of Hôpital Ste. Justine, and Department of Pharmacology and Experimental Therapeutics, McGill University. Montreal. Quebec, Canada

\begin{abstract}
Free radicals have been implicated in the development of injury to the immature retina. Asphyxia increases free radicals as well as prostaglandins (PG) in neural tissues. We assessed whether in the retina the cyclooxygenase pathway contributes to free radical formation after oxidative insults such as asphyxia, which in turn disrupts retinal function. Newborn pigs were treated with either saline, ibuprofen (194 $\mu \mathrm{mol} / \mathrm{kg}$ i.v.), or allopurinol (1 $\mathrm{mmol} / \mathrm{kg}$ i.v.), and retinal malondialdehyde (MDA), hydroperoxides, $\mathrm{PGE}_{2}$ and $\mathrm{PGF}_{2 \alpha}$ levels, and the amplitudes and implicit times of the a- and b-waves of the full-field electroretinogram were measured before and $1 \mathrm{~h}$ after a 5-min period of asphyxia. In saline-treated animals, asphyxia caused a marked increase $(p<0.01)$ in MDA, hydroperoxides, $\mathrm{PGE}_{2}$, and $\mathrm{PGF}_{2 \alpha}$ concentrations in the retina. This was associated with a significant decrease ( $p$ $<0.01$ ) in the b-wave amplitude measured under scotopic and photopic conditions and an increase in the b-wave implicit times. Ibuprofen and another cyclooxygenase inhibitor, indomethacin ( $28 \mu \mathrm{mol} / \mathrm{kg}$ i.v.), decreased $\mathrm{PGE}_{2}$ and $\mathrm{PGF}_{2 \alpha}$ levels and prevented the increase in MDA and hydroperoxides after asphyxia. Allopurinol maintained low concentrations of MDA and hydroperoxides after asphyxia. Both ibuprofen and allopurinol prevented the postasphyxial changes in the b-wave amplitude and diminished the delay in implicit time observed after asphyxia in saline-treated pigs. Our findings suggest that in the retina after asphyxia free radicals appear to originate primarily from the cyclooxygenase pathway and contribute to the deterioration in retinal electrophysiologic function of the newborn animal. Cyclooxygenase inhibitors, like free radical scavengers, may protect retinal function from deteriorating after oxidative stresses. (Pediatr Res 33: 336-340, 1993)
\end{abstract}

Abbreviations

ERG, electroretinogram

MDA, malondialdehyde

PG, prostaglandin
Free radicals and PG increase in the retina and other neural tissues after asphyxia $(1,2)$. However, in contrast to primary PG, which may even be cytoprotective $(3,4)$, free radicals have been clearly shown to cause tissue damage, including disruption of retinal cellular morphology $(5,6)$ and electrophysiologic function $(7,8)$.

Free radicals can arise from various metabolic sources including the cyclooxygenase pathway $(9,10)$. In some tissues after certain types of oxidative stresses, such as after an ischemic insult to the heart and brain, the cyclooxygenase pathway is a major source of free radicals $(11-14)$.

There exists increasing evidence that lipid peroxides, formed from the oxidation of unsaturated fatty acids by superoxide and/ or hydroxyl radicals, may be implicated in damage to the immature retina $(15,16)$. However, it is unknown whether in the retina the cyclooxygenase pathway contributes significantly to free radical formation after oxidative insults such as asphyxia and in turn causes disruption of retinal function. Because PG (1) and free radicals (2) increase in neural tissue after asphyxia, we speculated that the free radicals produced in the retina after asphyxia arise largely from the cyclooxygenase pathway and cause damage to this tissue. To test this hypothesis, newborn pigs were treated with the cyclooxygenase inhibitor ibuprofen and lipid peroxide levels and retinal electrophysiologic function, assessed before and after asphyxia, were compared with those of animals treated with the neuroprotective free radical scavenger allopurinol (14, 17).

\section{MATERIALS AND METHODS}

This study was approved by the Animal Care Committee of Hôpital Ste. Justine.

The newborn pig was selected as our model bec ause its retina has characteristics similar to those of the human retina. The retina of the piglet contains both rods and cones (18), with the latter being centrally concentrated, it is holangiotic without a tapetum (19), and it has separate retinal and choroidal blood supplies (20).

Surgical Preparation. One- to 3-d-old pigs (1.4-2.0 kg) were anesthetized with halothane $(0.5 \%)$. A femoral artery was catheterized with a polyethylene umbilical catheter (Argyle, 31/2 French, Sherwood, St. Louis, MO) to measure blood pressure using a Statham pressure transducer (Gould Inc, Valley View, $\mathrm{OH}$ ) connected to a multichannel recorder (TA240, Gould Inc) and to sample blood for measurement of $\mathrm{pH}, \mathrm{PO}_{2}$, and $\mathrm{PCO}_{2} . \mathrm{A}$ small polyethylene catheter (Intramedic PE-50, Becton Dickinson \& Co, Parsippany, NJ) was placed in the femoral vein for administration of drugs. Tracheostomy was performed and the animals were ventilated (small animal respirator. Harvard Apparatus Co., South Natick, MA) with air.
Received August 24, 1992; accepted December 17, 1992.
Correspondence: Sylvain Chemtob, M.D. Ph.D., Research Center of Hôpital Ste. Justine, Departments of Pediatrics and Pharmacology, 3175 Côte Ste. Catherine, Montreal, Quebec, H3T-1C5 Canada.

Supported in part by grants from the Medical Research Council of Canada, the Fonds de la Recherche en Santé du Québec, and Biopedia Inc. 
After the surgery, halothane was discontinued and the animals were injected i.v. with $\alpha$-chloralose $(161 \mu \mathrm{mol} / \mathrm{kg}$ followed by 32 $\mu \mathrm{mol} / \mathrm{kg} / \mathrm{h} ; 50 \mathrm{mg} / \mathrm{kg}$ and $10 \mathrm{mg} / \mathrm{kg} / \mathrm{h}$, respectively) and paralyzed with pancuronium $[0.14 \mu \mathrm{mol} / \mathrm{kg}(0.1 \mathrm{mg} / \mathrm{kg})$, twice $]$, Animals were placed prone on a cloth sling and their body temperature was maintained at $38^{\circ} \mathrm{C}$ using a heating pad. The piglets were allowed to stabilize for approximately $1^{1 / 2} \mathrm{~h}$ before the experiments were started.

Experimental Protocol and ERG. Animals were randomly assigned to receive an i.v. injection of saline ( $1-2 \mathrm{~mL} / \mathrm{kg}, n=7)$, ibuprofen [194 $\mu \mathrm{mol} / \mathrm{kg}(40 \mathrm{mg} / \mathrm{kg}), n=7$ ], or allopurinol [1 $\mathrm{mmol} / \mathrm{kg}(140 \mathrm{mg} / \mathrm{kg}), n=6] 45 \mathrm{~min}$ before the first ERG was recorded. The doses of drugs were selected because they have been previously shown to inhibit prostanoid synthesis and to reduce lipid peroxide levels in the CNS and retina or to exhibit neuroprotective properties $(14,17,21)$. Although allopurinol is also a xanthine oxidase inhibitor at much lower doses, the doses used in this study also produce primarily free radical scavenging effects (17).

The pupils were maximally dilated with $1 \%$ cyclopentolate. ERG were recorded using corneal lens unipolar electrodes (ERGJet, Universo, La-Chaux-de-Fonds Switzerland) placed on each cornea humidified with hydroxypropylmethylcellulose. Reference and ground electrodes were placed above the eyelids and neck, respectively. The heads of the animals were positioned inside a Ganzfeld stimulator (LKB Technologies Inc., Gaithersburg, MD) of 44-cm diameter. The flash stimulus (Grass Instrument Co., Quincy, MA) was set at $3.65 \mathrm{~cd} \cdot \mathrm{s} / \mathrm{m}^{2}$.

ERG were obtained as we previously reported (22). The pigs were kept in a dark chamber for $30 \mathrm{~min}$ before a baseline scotopic (dark-adapted; combined rod/cone response) standardized fullfield ERG was recorded. After 10 min of light adaptation at an illumination of $34.6 \mathrm{~cd} / \mathrm{m}^{2}$, the photopic (light-adapted; selective cone) responses were determined. The pigs were then asphyxiated by interrupting ventilation for exactly 5 min, using a model of apneic asphyxia previously described $(1,2)$. Thirty min after the asphyxial period, the animals were dark-adapted for another 30 min, after which scotopic ERG were recorded; 10 min after light adaptation, photopic responses were again determined. Thus, standardized protocol ERG were recorded before and $60 \mathrm{~min}$ after asphyxia; this latter time was selected in accordance with a deterioration in retinal hemodynamics that we observed in preliminary studies (23).

ERG signals were amplified using an Epic 2000 electrodiagnostic instrument (LKB Technologies Inc.) at a bandwidth of 0.3 to $500 \mathrm{~Hz}$. To assure accuracy and reproducibility of the electrophysiologic signals, a minimum of five responses for each scotopic and photopic ERG were recorded and then stored on computer disk for subsequent analysis. For each averaged ERG, the amplitudes and implicit times of the a-wave (generated by the photoreceptors) and b-wave (generated largely by the Müller glial cells) were measured. The amplitude of the a-wave was calculated as the difference in voltage from baseline to the maximum negative deflection of the first portion of the ERG, and the amplitude of the b-wave was calculated from this negative deflection (of the a-wave) to the maximum positive deflection (see Fig. 1). The implicit times for both waves were calculated as the times from the flash onset to the peak of each wave.

The results are presented as the difference between preasphyxial and postasphyxial values for scotopic and photopic aand b-wave amplitude and implicit time. Arterial blood gases were also measured at the same times and $10 \mathrm{~s}$ before the end of the asphyxial period.

Measurements of MDA, Hydroperoxides, $P G F_{2 \alpha}$, and $\mathrm{PGE}_{2}$. To measure in the retina the levels of the lipid peroxides, MDA and hydroperoxides, and of the major retinal $\mathrm{PG}, \mathrm{PGE}_{2}$ and $\mathrm{PGF}_{2 \alpha}(21)$, experiments were also performed on 21 separate animals $(1.2-2.1 \mathrm{~kg})$ treated as described above and killed [with pentobarbital $0.5 \mathrm{mmol} / \mathrm{kg}(120 \mathrm{mg} / \mathrm{kg})$ i.v.] either before or 60 min after asphyxia $(n=3-4$ per time period per treatment group). In addition. we tested whether the effects of ibuprofen on MDA levels could be reproduced by indomethacin, a structurally unrelated cyclooxygenase inhibitor. Seven pigs were treated with indomethacin $[28 \mu \mathrm{mol} / \mathrm{kg}(10 \mathrm{mg} / \mathrm{kg})$ i.v.], a dose that completely inhibits cyclooxygenase in the retina (21), and the animals were killed before or $60 \mathrm{~min}$ after asphyxia. Mean blood pressure, heart rate, and arterial blood gases and $\mathrm{pH}$ measured before, at the end of the period of asphyxia, and $1 \mathrm{~h}$ later were nearly identical to those of animals from which ERG were recorded (Table 1). Immediately after animals were killed, liquid $\mathrm{N}_{2}$ was poured on each eye; the eyes were then removed and stored at $-80^{\circ} \mathrm{C}$ until the assay was performed within $1 \mathrm{mo}$ of storage; all products measured were stable over this time period.

The retinas were removed on ice and suspended in a cold buffer ( $\mathrm{pH}$ 7.4) of the following composition: $5 \mathrm{mM}$ Tris- $\mathrm{HCl}$, $0.67 \mathrm{mM}$ acetylsalicylic acid, $0.5 \mathrm{mM}$ EGTA, and $100 \mu \mathrm{M}$ butylated hydroxytoluene. The tissue was homogenized and centrifuged at $1000 \times g$ for $10 \mathrm{~min}$ to remove undisrupted cells and nuclei. Protein (24), MDA, hydroperoxides, $\mathrm{PGF}_{2 \alpha}$, and $\mathrm{PGE}_{2}$ were assayed on the supernatant. The protein content of each eye was not changed by the asphyxia (preasphyxia: $2.8 \pm 0.2 \mathrm{mg}$; postasphyxia: $2.8 \pm 0.1 \mathrm{mg}$ ).

MDA measurements. MDA was measured by the thiobarbituric acid reaction (25). Briefly, the samples were added to a 17 $\mathrm{mM}$ solution of thiobarbituric acid further acidified with acetic acid and heated to $90-100^{\circ} \mathrm{C}$ for $1 \mathrm{~h}$. After cooling, 1-butanol was added and the samples were centrifuged at $1000 \times g$ for 10 min. Absorbance of the upper phase was read at $532 \mathrm{~nm}$ (DU64, Beckman spectrophotometer). Standard curves were obtained with malonaldehyde bisdimethyl acetal (26); the interassay variability was $\leq 2.5 \%$.

Hydroperoxide measurements. Hydroperoxides were measured to obtain a desirable additional index of peroxidation. These were determined by oxidation of $\mathrm{FeCl}_{2}, 250 \mu \mathrm{M}$, under acidic conditions $\left(\mathrm{H}_{2} \mathrm{SO}_{4}, \mathrm{pH}=2-3\right)$ in the presence of butylated hydroxytoluene, $4 \mathrm{mM}$, and xylenol orange, $100 \mu \mathrm{M}$, and the absorption was read at $560 \mathrm{~nm}$ (27). Standard curves were obtained with t-butyl-hydroperoxide; the interassay variability was $<3.5 \%$.

$P G$ measurements. For determination of $\mathrm{PG}$, the supernatant obtained after homogenization, as described above, was further centrifuged at $50000 \times g$ for $30 \mathrm{~min}$ at $4^{\circ} \mathrm{C}$ to remove membranes to enhance extraction of PG on octadecylsilyl silica columns (28). PG were extracted according to the method of Powell (28). The supernatant was dissolved in $15 \%$ ethanol and acidified to $\mathrm{pH} 3$ with glacial acetic acid. The samples were applied to octadecylsilyl silica columns, which were then washed with $15 \%$ aqueous ethanol followed by petroleum ether, and the PG were subsequently eluted with methyl formate. The efficiency of recovery after extraction for all PG measured was $>96 \%$.

$\mathrm{PGF}_{2 \alpha}$ and $\mathrm{PGE}_{2}$ were measured by RIA technique, as we have described (21). The interassay variability was $<5 \%$.

Drugs and Chemicals. Ibuprofen, indomethacin, allopurinol, acetylsalicylic acid, thiobarbituric acid, malonaldehyde bisdimethyl acetal, butylated hydroxytoluene, xylenol orange, and tbutyl-hydroperoxide were purchased from Sigma Chemical Co. (St. Louis, MO). RIA kits for $\mathrm{PGF}_{2 \alpha}$ and $\mathrm{PGE}_{2}$ were obtained from Advanced Magnetics (Boston, MA). Ibuprofen and indomethacin were dissolved in $\mathrm{NaCl} 150 \mathrm{mM}$ and $\mathrm{NaOH} 0.3 \mathrm{~N}$ titrated to $\mathrm{pH} 7.4$ (21). Allopurinol was dissolved in $\mathrm{NaCl} 150$ $\mathrm{mM}$ alkalinized with $\mathrm{NaOH}$ to $\mathrm{pH} 11$ (14). All other chemicals were purchased from Fisher Laboratories (Montreal, Quebec, Canada).

Statistical Analysis. No significant differences in ERG parameters were found between the right and left eyes. Thus, for each pair of eyes, an average of the measures for each parameter was calculated.

Statistical analyses were performed by univariate analysis of variance for repeated measures and two-way analysis of variance, 


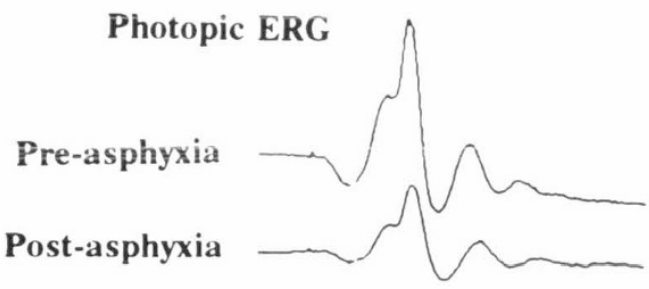

Saline

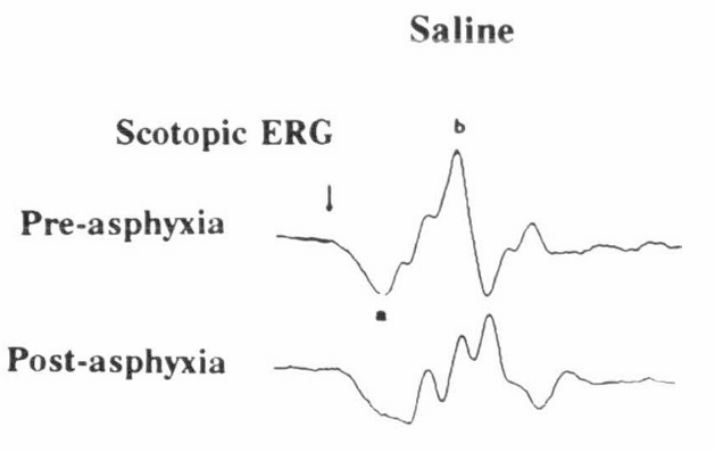

(n)
Ibuprofen
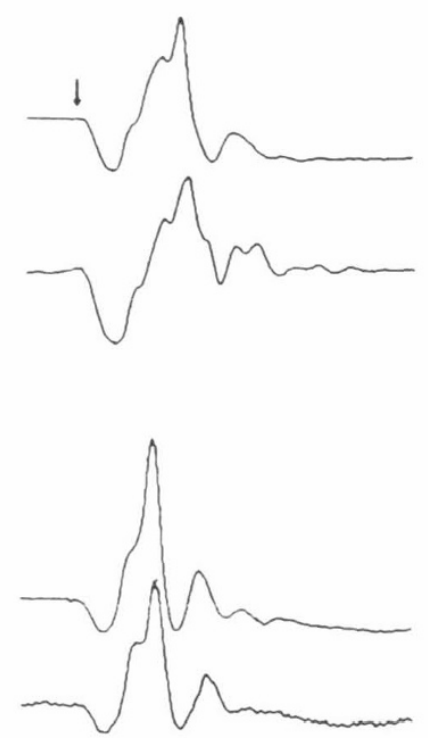

Allopurinol 
Table 2. Difference between preasphyxial and postasphyxial $E R G a$-and b-wave amplitudes and implicit times in piglets treated with saline, ibuprofen, and allopurinol*

\begin{tabular}{lccc}
\hline & Saline & $\begin{array}{c}\text { Ibuprofen } \\
(194 \mu \mathrm{mol} / \mathrm{kg}, \\
n=7)\end{array}$ & $\begin{array}{c}\text { Allopurinol } \\
(1 \mathrm{mmol} / \mathrm{kg}, \\
n=6)\end{array}$ \\
& & & \\
a-Wave & & & \\
Scotopic & & & \\
$\quad$ Amplitude $(\mu \mathrm{V})$ & $-25.3 \pm 6.5 \dagger$ & $-2.4 \pm 2.6 \ddagger$ & $-8.2 \pm 3.3 \dagger \ddagger$ \\
Implicit time $(\mathrm{ms})$ & $1.7 \pm 0.8$ & $1.4 \pm 0.4$ & $-0.1 \pm 1.0$ \\
Photopic & & & \\
Amplitude $(\mu \mathrm{V})$ & $-6.4 \pm 4.3$ & $-3.3 \pm 1.6$ & $-3.6 \pm 1.8$ \\
Implicit time $(\mathrm{ms})$ & $1.7 \pm 0.8$ & $1.4 \pm 0.4$ & $-0.1 \pm 1.0$ \\
b-Wave & & & \\
Scotopic & & & \\
Amplitude $(\mu \mathrm{V})$ & $-51.4 \pm 9.2 \dagger$ & $-1.6 \pm 6.9 \ddagger$ & $-5.8 \pm 12.5 \ddagger$ \\
Implicit time $(\mathrm{ms})$ & $6.8 \pm 0.9 \dagger$ & $4.3 \pm 0.8 \dagger \ddagger$ & $3.4 \pm 1.0 \dagger \ddagger$ \\
Photopic & & & \\
Amplitude $(\mu \mathrm{V})$ & $-47.5 \pm 10.5 \dagger$ & $-10.2 \pm 5.5 \ddagger$ & $-24.8 \pm 9.9 \ddagger$ \\
Implicit time $(\mathrm{ms})$ & $3.5 \pm 0.8 \dagger$ & $2.5 \pm 0.7 \dagger$ & $1.7 \pm 0.7 \ddagger$ \\
\hline
\end{tabular}

*Values are mean \pm SEM, calculated as the value of amplitide and implicit time $1 \mathrm{~h}$ after a 5 -min asphyxial period minus that before asphyxia in the same animal.

$\dagger p<0.02$ compared with a value of 0 .

$\ddagger p<0.05$ compared with saline-treated animals.

Table 3. Concentrations of MDA, hydroperoxides, $P G F_{2 \alpha}$, and $P G E_{2}$ in retina before and $1 \mathrm{~h}$ after 5 -min period of asphyxia in piglets treated with saline, ibuprofen, indomethacin, and allopurinol*

$1 \mathrm{~h}$

\begin{tabular}{|c|c|c|}
\hline & Preasphyxia & $\begin{array}{c}1 \mathrm{~h} \\
\text { Postasphyxia }\end{array}$ \\
\hline \multicolumn{3}{|l|}{ Saline } \\
\hline MDA (nmol/mg protein) & $12.4 \pm 0.5$ & $27.4 \pm 0.2 \dagger$ \\
\hline $\begin{array}{l}\text { Hydroperoxides } \\
\text { (nmol/mg protein) }\end{array}$ & $2.9 \pm 0.5$ & $103.6 \pm 10.5 \dagger$ \\
\hline $\mathrm{PGF}_{2 \alpha}(\mathrm{pmol} / \mathrm{g}$ protein $)$ & $118.9 \pm 10.5$ & $215.3 \pm 8.7 \dagger$ \\
\hline $\mathrm{PGE}_{2}(\mathrm{pmol} / \mathrm{g}$ protein $)$ & $27.2 \pm 10.5$ & $44.9 \pm 11.6 \dagger$ \\
\hline \multicolumn{3}{|l|}{ Ibuprofen $(194 \mu \mathrm{mol} / \mathrm{kg})$} \\
\hline MDA (nmol/mg protein) & $13.8 \pm 0.9$ & $11.9 \pm 0.8$ \\
\hline $\begin{array}{l}\text { Hydroperoxides } \\
\text { (nmol/mg protein) }\end{array}$ & $2.8 \pm 0.4$ & $4.9 \pm 1.5$ \\
\hline $\mathrm{PGF}_{2 \alpha}(\mathrm{pmol} / \mathrm{g}$ protein $)$ & $24.2 \pm 3.1 \ddagger$ & $22.8 \pm 5.9$ \\
\hline $\mathrm{PGE}_{2}(\mathrm{pmol} / \mathrm{g}$ protein) & $5.1 \pm 1.7 \ddagger$ & $6.2 \pm 1.4$ \\
\hline \multicolumn{3}{|l|}{ Indomethacin $(28 \mu \mathrm{mol} / \mathrm{kg})$} \\
\hline MDA (nmol/mg protein) & $13.3 \pm 1.6$ & $11.7 \pm 1.3$ \\
\hline $\begin{array}{l}\text { Hydroperoxides } \\
\text { (nmol/mg protein) }\end{array}$ & $3.1 \pm 0.9$ & $2.5 \pm 0.8$ \\
\hline $\mathrm{PGF}_{2 \alpha}(\mathrm{pmol} / \mathrm{g}$ protein $)$ & $11.0 \pm 2.2 \ddagger$ & $5.4 \pm 1.7$ \\
\hline $\mathrm{PGE}_{2}(\mathrm{pmol} / \mathrm{g}$ protein) & $6.8 \pm 2.6 \ddagger$ & $9.7 \pm 2.7$ \\
\hline \multicolumn{3}{|l|}{ Allopurinol $(1 \mathrm{mmol} / \mathrm{kg})$} \\
\hline $\mathrm{MDA}(\mathrm{nmol} / \mathrm{mg}$ protein) & $9.1 \pm 0.6 \ddagger$ & $7.9 \pm 0.8$ \\
\hline $\begin{array}{l}\text { Hydroperoxides } \\
\text { (nmol/mg protein) }\end{array}$ & $<2$ & $4.6 \pm 1.8$ \\
\hline $\mathrm{PGF}_{2 \alpha}(\mathrm{pmol} / \mathrm{g}$ protein $)$ & ND & ND \\
\hline $\mathrm{PGE}_{2}$ (pmol/g protein) & ND & ND \\
\hline
\end{tabular}

* Each value is a mean \pm SEM of three to four experiments. ND, not determined.

$\dagger p<0.01$ compared with preasphyxia value.

$\ddagger p<0.01$ compared with corresponding value after saline treatment.

change the preasphyxial concentrations of MDA and hydroperoxides (compared with saline, $p>0.2$ ) but maintained the latter two at constant levels after asphyxia. Allopurinol decreased the levels of MDA and hydroperoxides and kept them stable after asphyxia.
DISCUSSION

Our findings suggest that, in the retina, lipid peroxides originate to a large extent from the cyclooxygenase pathway and contribute significantly to the deterioration in retinal electrophysiologic function of the newborn animal. Cyclooxygenase inhibitors, like free radical scavengers, blocked the increase in MDA and hydroperoxides and significantly attenuated the deterioration in retinal function occurring after asphyxia.

Lipid peroxidation involves the formation and propagation of lipid radicals after the generation of superoxide and/or hydroxyl radicals that abstract a hydrogen atom from an unsaturated fatty acid. Hydroperoxides are by-products and MDA is a further breakdown product of lipid peroxidation $(25,29)$. After asphyxia, there was an increase in the levels of MDA and a larger increase in the levels of hydroperoxides in the retina, and these changes were abolished by free radical scavenging doses of allopurinol (Table 3) (17); the sensitivity of hydroperoxide measurements is greater than that of MDA (27). Similar increases of other indices of lipid peroxidation, namely fluorescent compounds and conjugated dienes, have been observed in the brain after asphyxia (2).

Free radicals arise from several sources; these include the metabolism of xanthine to uric acid via xanthine oxidase, as well as the metabolism of arachidonic acid via the cyclooxygenase and lipoxygenase pathways $(9,10)$. In certain tissues, such as the heart, xanthine oxidase contributes significantly to free radical formation after an oxidative stress such as ischemia (30). However, in the CNS, of which the retina is an integral part, xanthine dehydrogenase does not appear to convert readily to its oxidase form (31). These latter observations concur with ours. We found that PG increased concomitantly with the propagation of lipid radicals after asphyxia (high levels of hydroperoxides, Table 3 ), and that two structurally unrelated cyclooxygenase inhibitors, ibuprofen and indomethacin. completely inhibited the postasphyxial increase in retinal MDA and hydroperoxides. These findings suggested that the cyclooxygenase pathway, but not the xanthine oxidase or the lipoxygenase pathways (32), was the principal source of free radicals in the retina after asphyxia in the newborn animal (Table 3). Finally, basal MDA and hydroperoxide levels were not altered by ibuprofen and indomethacin; it is therefore unlikely these agents exerted a direct effect on lipid peroxide formation by chelating iron or scavenging free radicals to block lipid peroxide production (33).

The increases in retinal MDA and hydroperoxides observed after asphyxia were associated with a decrease in the b-wave amplitude and an increase in the implicit time of the ERG of saline-treated animals (Fig. 1. Table 2); the a-wave was generally minimally affected $(7,8)$, as previously reported. Ibuprofen. like allopurinol, which blocked the postasphyxial increases in lipid peroxides (Table 3 ), prevented the changes in the ERG that were observed after asphyxia in untreated animals (Fig. 1, Table 2). These findings further support the notion that in the retina the cyclooxygenase pathway contributes to free radical formation and functional deterioration after asphyxia.

Free radical scavengers and cyclooxygenase inhibitors have been shown to reduce neuronal damage and electrophysiologic function and to improve outcome after various types of oxidative stresses, such as asphyxia, ischemia, and hypoxia (13, 14, 3438). These findings in the brain are consistent with ours in the retina, which reveal that a cyclooxygenase inhibitor, ibuprofen, and a free radical scavenger, allopurinol (17), similarly attenuated the retinal electrophysiologic damage produced by asphyxia (Fig. 1. Table 2).

In the present study, we could not clearly identify whether the effects of asphyxia were caused by PG or by free radicals because both increased after asphyxia (Table 3). Nonetheless, certain inferences can be made. Free radicals have been shown to exert adverse effects on the retina, including the ERG pattern (7.8). Similarly, doses of PG nearly 10000 -fold higher than those 
normally present, applied directly to the vitreous in proximity to the retina have also been shown to decrease the b-wave amplitude (39); however, the physiologic significance of such excessive doses is unclear. Indeed, primary PG administered at more physiologic concentrations have not been shown to cause direct tissue damage; on the contrary, $\mathrm{PGE}_{2}$ and $\mathrm{PGI}_{2}$ may be cytoprotective ( 3 , 4). It would thus appear that the free radicals, rather than the PG, are major factors in the deterioration of the ERG pattern after asphyxia.

Asphyxia, which commonly occurs in sick preterm newborns because of respiratory difficulties, can potentially cause an increase in free radicals (Table 3), which have been implicated in the development of injury to the immature retina $(15,16)$. In other neural tissues, cyclooxygenase inhibitors improve clinical and electrophysiologic recovery after oxidative insults $(37,38)$. Some of these drugs such as ibuprofen, which markedly enhances the regulation of oxygen delivery to the retina (40), may ultimately become clinically useful to help protect retinal function from deteriorating after oxidative stresses. However, this speculation cannot apply to all cyclooxygenase inhibitors; for instance, indomethacin impairs retinal hemodynamics (21) and has even been associated, although not conclusively, with the development of retinopathy of prematurity (41).

In conclusion, the cyclooxygenase inhibitor ibuprofen, like the neuroprotective free radical scavenger allopurinol $(14,17)$, significantly attenuated the deterioration in the response of rods and cones to light after asphyxia and blocked the increase in retinal lipid peroxides. Our findings suggest that in the retina after asphyxia free radicals seem to originate primarily from the cyclooxygenase pathway and contribute to the deterioration in retinal function of the newborn animal. Long-term effects of specific cyclooxygenase inhibitors, such as ibuprofen, in reducing oxidative damage to the immature retina are currently under investigation.

Acknowledgment. The authors thank F. Ménard Inc. (AngeGardien, De Rouville, Quebec) for its generosity in supplying the newborn pigs.

\section{REFERENCES}

1. Pourcyrous M, Leffler C, Busija D 1988 Postasphyxial increases in prostanoids in cerebrospinal fluid of piglets. Pediatr Res 24:229-232

2. Goplerud JM, Mishra OP, Delivoria-Papadopoulos M 1992 Brain cell membrane dysfunction following acute asphyxia in newborn piglets. Biol Neonate 61:33-41

3. Robert A, Nezamis JE, Lancaster C, Hancher AJ 1979 Cytoprotection by prostaglandins in rats. Gastroenterology 77:433-443

4. Miller TA 1983 Protective effects of prostaglandins against gastric mucosal damage: current knowledge and proposed mechanisms. Am J Physiol 245:G601-G623

5. Tripathi BJ, Tripathi RC 1984 Cellular and subcellular events in retinopathy of oxygen toxicity with a preliminary report on the protective role of vitamin $\mathrm{E}$ and gamma-aminobutyric acid: a study in vitro. Curr Eye Res 3:193-208

6. Li ZY, Tso MOM, Wang H, Organisciak DT 1985 Amelioration of photic injury in rat retina by ascorbic acid: a histopathologic study. Invest Ophthalmol Vis Sci 26:1589-1598

7. Armstrong D, Hiramitsu T, Gutteridge J, Nilsson SE 1982 Studies on experimentally induced retinal degeneration. 1. Effect of lipid peroxides on electroretinographic activity in the albino rabbit. Exp Eye Res 35:157-171

8. Shvedova AA, Sidorov AS, Novikov KN, Galushchenko IV, Kagan VE 1979 Lipid peroxidation and electric activity of the retina. Vision Res 19:49-55

9. Egan RW, Gale PH, Baptista EM, Kennicott KL, Vanden Heuvel WJA, Walker RW, Fagerness PE, Kuehl Jr FA 1981 Oxidation reactions by prostaglandin cyclooxygenase-hydroperoxidase. J Biol Chem 256:7352-7361

10. Kukreja RC, Kontos HA, Hess ML, Ellis EF 1986 PGH synthase and lipoxygenase generate superoxide in the presence of NADH or NADPH. Circ Res 59:612-619

11. Simpson PJ, Lucchesi BR 1987 Free radicals and myocardial ischemia and reperfusion injury. J Lab Clin Med 110:13-30

12. Romson JL, Hook BG, Rigot VH, Schork MA, Swanson DP, Lucchesi BR 1982 The effect of ibuprofen on accumulation of 111 -indium labeled platelets and leukocytes in experimental myocardial infarction. Circulation 66:10021011

13. Rosenberg AA, Mudaugh E, White CW 1989 The role of oxygen free radicals in postasphyxia cerebral hypoperfusion in newborn lambs. Pediatr Res 26:215-219

14. Palmer C. Vannucci RC. Towfighi J 1990 Reduction of perinatal hypoxicischemic brain damage with allopurinol. Pediatr Res 27:332-336

15. Penn JS 1992 Oxygen-induced retinopathy in the rat: a proposed role for peroxidation reactions in the pathogenesis. In: Treinen Moslen M. Smith CV (eds) Free Radical Mechanisms of Tissue Injury. CRC Press, Boca Raton, FL, pp 177-188

16. Yagi K, Matsuoka S, Ohkawa H, Ohishi N, Takevchi Y, Kakai H 1977 Lipoperoxide level of the retina of the chick embryo exposed to high concentration of oxygen. Clin Chim Acta 80:355-360

17. Moorhouse PC, Grootveld M, Halliwell B, Quinlan JG, Gutteridge JMC 1987 Allopurinol and oxypurinol are hydroxyl radical scavengers. FEBS Lett 213:23-28

18. Beauchemin ML, Babel J 1973 Proceedings: A preliminary study on the ultrastructure of the pig retina. Exp Eye Res 17:400

19. Prince JH, Ruskell GL 1960 The use of domestic animals for experimental ophthalmology. Am J Ophthalmol 49:1202-1207

20. Bloodworth Jr JM, Gutgesall Jr HP, Engerman RL 1965 Retinal vasculature of the pig. Light and electron microscope studies. Exp Eye Res 4:174-178

21. Parys-Van Ginderdeuren R, Malcolm D, Varma DR, Aranda JV, Chemtob S 1992 Dissociation between prostaglandin levels and blood flow to the retina and choroid in the newborn pig following nonsteroidal antiinflammatory drugs. Invest Ophthalmol Vis Sci 33:3378-3384

22. Lachapelle P, Benoit J, Blain L, Guitte P, Roy MS 1990 The oscillatory potentials in response to stimuli of photopic intensities delivered in darkadaptation: an explanation for the conditioning flash effect. Vision Res 30:503-513

23. Chemtob S, Ghosdi A, Barna T 1991 Prostanoids contribute significantly to the changes in retinal blood flow autoregulation following asphyxia of the newborn pig. Invest Ophthalmol Vis Sci 32:864(abstr)

24. Bradford MM 1976 A rapid and sensitive method for the quantitation of microgram quantities of protein utilizing the principle of protein-dye binding. Anal Biochem 72:248-254

25. Buege JA, Aust SD 1978 Microsomal lipid peroxidation. Methods Enzymol 52:302-310

26. Sinnhuber RO, Yu IC, Yu TC 1958 Characterization of the red pigment formed in 2-thiobarbituric acid determination of oxidative rancidity. Food Res 23:620-633

27. Jiang Z-Y, Woollard ACS, Wolff SP 1991 Lipid hydroperoxide measurement by oxidation of $\mathrm{Fe}^{+2}$ in the presence of xylenol orange. Comparison with the TBA assay and an iodometric method. Lipids 26:853-856

28. Powell WS 1982 Rapid extraction of arachidonic acid metabolites from biological samples using octadecylsilyl silica. Methods Enzymol 86:467-477

29. Valenzuela A 1991 The biological significance of malondialdehyde determination in the assessment of tissue oxidative stress. Life Sci 48:301-309

30. McCord JM 1985 Oxygen-derived free radicals in postischemic tissue injury, N Engl J Med 312:159-163

31. Mink R, Dutka AJ, Kumaroo KK, Hallenbeck JM 1990 No conversion of xanthine dehydrogenase to oxidase in canine cerebral ischemia. Am J Physiol 259:H1655-H1659

32. Kontos HA 1987 Oxygen radicals from arachidonate metabolism in abnormal vascular responses. Am Rev Respir Dis 136:474-477

33. Kennedy TP, Rao NV, Noah W, Michael JR, Jafri Jr MH. Gurtner GH. Hoidal JR 1990 Ibuprofen prevents oxidant lung injury and in vitro lipid peroxidation by chelating iron. J Clin Invest 86:1565-1573

34. Thiringer K. Hrbek A, Karlsson K, Rosén KG, Kjellmer I 1987 Postasphyxial cerebral survival in newborn sheep after treatment with oxygen free radical scavengers and a calcium antagonist. Pediatr Res 22:62-66

35. Perkins WJ, Newberg Milde L, Milde JH, Michenfelder JD 1991 Pretreatment with $\mathrm{U} 74006 \mathrm{~F}$ improves neurologic outcome following complete cerebral ischemia in dogs. Stroke 22:902-909

36. Mink RB, Dutka AJ, Hallenbeck JM 1991 Allopurinol pretreatment improves evoked response recovery following global cerebral ischemia in dogs. Stroke 22:660-665

37. Sasaki T, Nakagomi T, Kirino T, Tamura A, Noguchi M, Saito I, Takakura K 1988 Indomethacin ameliorates ischemic neuronal damage in the hippocampal CA, sector. Stroke 19:1399-1403

38. Taylor MD, Mellert TK, Parmentier JL, Eddy LJ 1985 Pharmacological protection of reoxygenation damage to in vitro brain slice tissue. Brain Res 347:268-273

39. Wallenstein MC, Bito LZ 1978 The effects of intravitreally injected prostaglan$\operatorname{din} E_{1}$ on retinal function and their enhancement by a prostaglandintransport inhibitor. Invest Ophthalmol Vis Sci 17:795-799

40. Chemtob S, Beharry K, Rex J, Chatterjee T, Varma DR, Aranda JV 1991 Ibuprofen enhances retinal and choroidal blood flow autoregulation in newborn piglets. Invest Ophthalmol Vis Sci 32:1799-1807

41. Gersony WM, Peckham GJ, Ellison RC, Miettinen OS, Nadas AS 1983 Effects of indomethacin in premature infants with patent ductus arteriosus: results of a national collaborative study. J Pediatr 102:895-907 